\title{
The complete genome sequence of the cold adapted crude-oil degrader: Pedobacter steynii DX4
}

\author{
Sijing Chang ${ }^{1,2,3}$, Gaosen Zhang ${ }^{3,4}$, Ximing Chen ${ }^{3,4}$, Haozhi Long ${ }^{4,5}$, Yilin Wang ${ }^{5}$, Tuo Chen ${ }^{2,3^{*}}$ and Guangxiu Liu Li,4 $^{3,4}$
}

\begin{abstract}
Pedobacter steynii DX4 was isolated from the soil of Tibetan Plateau and it can use crude oil as sole carbon and energy source at $15^{\circ} \mathrm{C}$. The genome of Pedobacter steynii DX4 has been sequenced and served as basis for analysis its metabolic mechanism. It is the first genome of crude oil degrading strain in Pedobacter genus. The $6.58 \mathrm{Mb}$ genome has an average $\mathrm{G}+\mathrm{C}$ content of $41.31 \%$ and encodes 5464 genes. In addition, annotation revealed that Pedobacter steynii DX4 has cold shock proteins, abundant response regulators for cell motility, and enzymes involved in energy conversion and fatty acid metabolism. The genomic characteristics could provide information for further study of oil-degrading microbes for recovery of crude oil polluted environment.
\end{abstract}

Keywords: Pedobacter, Crude oil, Degradation, Genome

\section{Introduction}

The crude oil spills occur frequently and they bring serious pollution to the terrestrial and marine environments $[1,2]$. In the bioremediation of crude oil contamination, bacteria work as primary degraders [3-5]. Numerous strains be capable of degrading hydrocarbons have been singled out and identified from marine and terrestrial environments [6-8]. It was also reported that in oil polluted areas, Pedobacter is one of the major members of alkane degrading bacterial communities [9-11]. For the first time in Pedobacter genus, a cultured Pedobacter cryoconitis strain was described to have the ability to degrade crude oil [12]. The Pedobacter steynii strain DX4 was isolated from frozen soil of Tibetan Plateau permafrost region. This organism was selected for genome sequencing for it exhibited the capability to utilize and degrade crude oil at a cold temperature $\left(15^{\circ} \mathrm{C}\right)$. In this paper, our aim was to identify genomic signatures for petroleum degradation in this strain, and investigate its application in bioremediation in cold environments.

\footnotetext{
* Correspondence: chentuo@lzb.ac.cn

${ }^{2}$ State Key Laboratory of Cryospheric Sciences, Northwest Institute of Eco-Environment and Resources, Chinese Academy of Sciences, Lanzhou 730000, China

${ }^{3}$ Key Laboratory of Extreme Environmental Microbial Resources and Engineering, Gansu Province 730000, China

Full list of author information is available at the end of the article
}

\section{Organism information}

Classification and features

The soil sample was collected from the Dangxiong County $\left(30.5633^{\circ} \mathrm{N}, 91.4221^{\circ} \mathrm{E}, 4488 \mathrm{~m} \mathrm{ASL}\right)$ in the Tibetan Plateau, in 2013. The soil sample was preserved at $-20{ }^{\circ} \mathrm{C}$ immediately after collection and sent to the State Key Laboratory of Cryospheric Sciences, CAS. The soil type belongs to alpine meadow soil. Crude-oil degrading strains were enriched in liquid MM medium added $2 \%$ crude oil $(v / v)$ and incubated for 2 weeks at $20{ }^{\circ} \mathrm{C}$ [13]. The suspension of culture collection was surface spread onto the $216 \mathrm{~L}$ agar plates and cultivated for 5 days at $20{ }^{\circ} \mathrm{C}$ [14]. DX4 colonies on $216 \mathrm{~L}$ agar plates are light yellow, slightly domed mucoid and circular with smooth margins. DX4 cells are Gram negative rods, motile, nonspore-forming. The scanning electron micrograph is shown in Fig. 1. Additional characteristics of P. steynii DX4 are shown in Table 1. Growth experiment was carried out in $216 \mathrm{~L}$ liquid medium at $20^{\circ} \mathrm{C}$ and the $\mathrm{OD}_{600}$ of strain DX4 is shown in Fig. 2. In addition, Fig. 3 shows the crude oil degradation rates of the strain DX4. The degradation was carried out in liquid MM medium added $2 \%$ crude oil $(\mathrm{v} / \mathrm{v})$ at $15{ }^{\circ} \mathrm{C}$ for 2 weeks and crude oil was quantified by using gas chromatography and mass spectrometric detector [15]. 


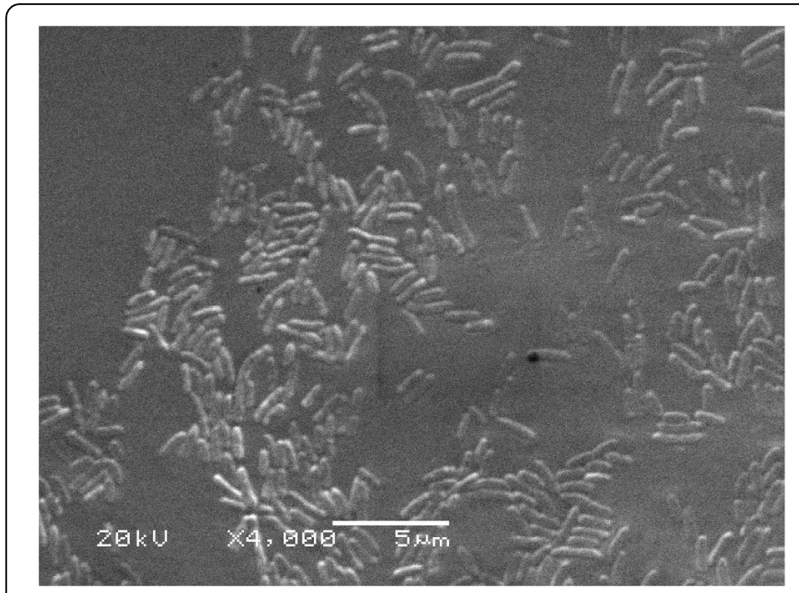

Fig. 1 Scanning electron micrograph of P. steynii DX4
The molecular identification was performed with the 27F-1492R primer to amplify the $16 \mathrm{~S}$ rRNA sequence. The 16S rRNA from DX4 was $99.64 \%$ similar to the Pedobacter steynii WB2.3-45 ${ }^{\mathrm{T}}$ (AM491372) thus DX4 was identified as a strain of $P$. steynii.

Figure 4 shows the phylogenetic tree constructed from the 16S rRNA sequence together with other related Pedobacter species using MEGA 5.0 software suite. The evolutionary history was inferred by using Neighbor-joining method based on the maximum composite likehood substitution model $[16,17]$.

\section{Genome sequencing information}

Genome project history

The strain DX4 was selected for sequencing on the basis of its potential biodegradation capability. The initial Illumina sequencing was performed in April 2016 and the genome was closed by PacBio sequencing in August

Table 1 Classification and general features of Pedobacter steynii DX4

\begin{tabular}{|c|c|c|c|}
\hline MIGS ID & Property & Term & Evidence code \\
\hline & \multirow[t]{8}{*}{ Classification } & Domain Bacteria & TAS [41] \\
\hline & & Phylum Bacteroidetes & $\operatorname{TAS}[42,43]$ \\
\hline & & Class Sphingobacteriia & TAS [44-46] \\
\hline & & Order Sphingobacteriales & TAS [44] \\
\hline & & Family Sphingobacteriaceae & $\operatorname{TAS}[47,48]$ \\
\hline & & Genus Pedobacter & TAS [49] \\
\hline & & Species Pedobacter steynii & TAS [49] \\
\hline & & Strain DX4 & \\
\hline & Gram stain & Negative & TAS [49] \\
\hline & Cell shape & Rod & IDA \\
\hline & Motility & Motile & TAS [49] \\
\hline & Sporulation & Non-sporulating & TAS [49] \\
\hline & Temperature range & $4-25^{\circ} \mathrm{C}$ & IDA \\
\hline & Optimum temperature & $20^{\circ} \mathrm{C}$ & TAS [50] \\
\hline & pH range; Optimum & $5-10 ; 7.5$ & IDA \\
\hline & Carbon source & Yeast extract, pyruvate, crude oil & IDA \\
\hline MIGS-6 & Habitat & Frozen soil & IDA \\
\hline MIGS-6.3 & Salinity & $0.5-4.5 \% \mathrm{NaCl}(w / v)$ & TAS [51] \\
\hline MIGS-22 & Oxygen requirement & Aerobic & NAS \\
\hline MIGS-15 & Biotic relationship & Free-living & IDA \\
\hline MIGS-14 & Pathogenicity & Non-pathogen & NAS \\
\hline MIGS-4 & Geographic location & China: Tibetan Plateau, Dangxiong County & IDA \\
\hline MIGS-5 & Sample collection & 2013 & IDA \\
\hline MIGS-4.1 & Latitude & $30.5633^{\circ} \mathrm{N}$ & NAS \\
\hline MIGS-4.2 & Longitude & $91.4221^{\circ} \mathrm{E}$ & NAS \\
\hline MIGS-4.4 & Altitude & $4488 \mathrm{~m}$ & NAS \\
\hline
\end{tabular}

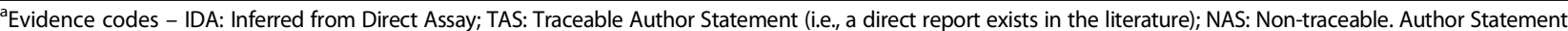
(i.e., not directly observed for the living, isolated sample, but based on a generally accepted property for the species, or anecdotal evidence). These evidence codes are from the Gene Ontology project 


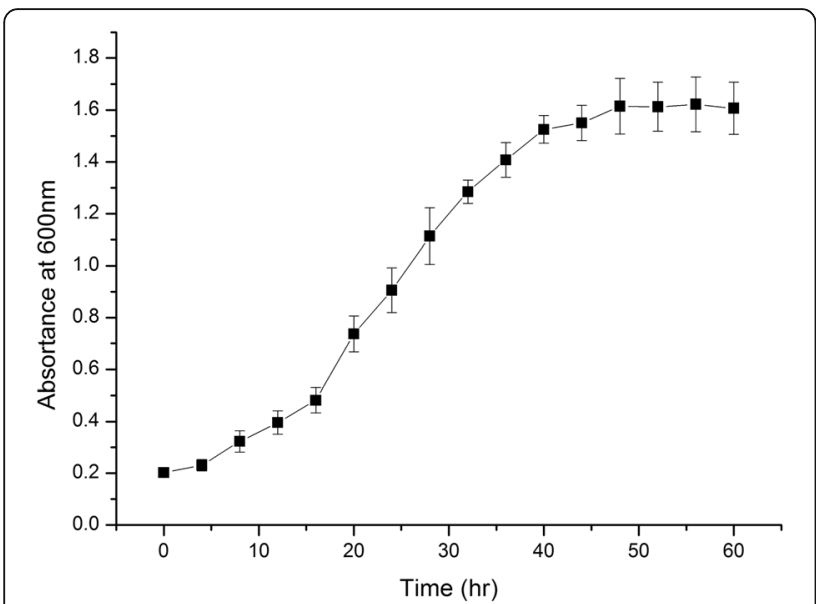

Fig. 2 Growth curve of P. steynii DX4 in $216 \mathrm{~L}$ liquid medium at $20{ }^{\circ} \mathrm{C}$. The absortance at $600 \mathrm{~nm}$ was measured every $4 \mathrm{~h}$

2016. The genome project is deposited in the online genome database (NCBI-Genome) and the sequence was released for public access on September 9, 2016. A summary of the project information is shown in the Table 2.

\section{Growth conditions and genomic DNA preparation}

Pedobacter steynii DX4 was inoculated into $216 \mathrm{~L}$ liquid medium and grown on a shaker $(200 \mathrm{rpm})$ at $20{ }^{\circ} \mathrm{C}$, until the cells $\mathrm{OD}_{600 \mathrm{~nm}}>1.0$. Genomic DNA was extracted from freshly grown cells using the E.Z.N.A. ${ }^{\circledR}$ Bacterial DNA

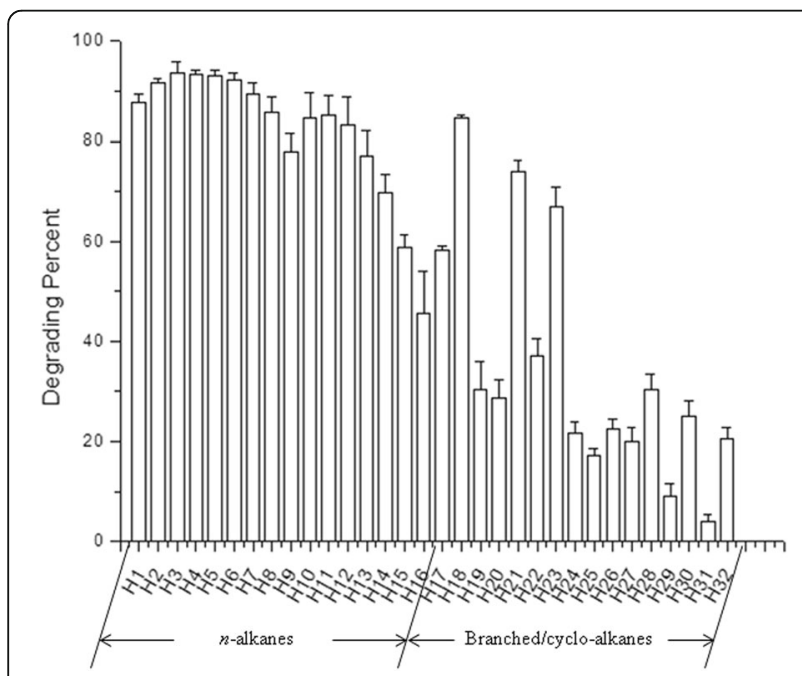

Fig. 3 Degrading rates of crude oil by P. steynii DX4. H1 - H16: serial n-alkanes, from Undecane to Hexacosane. H17- H32: branched alkanes and cycloalkanes, in accordance with the order: Undecane,2,6-dimethyl; Dodecane,2-methyl; Dodecane,2,6,11-trimethyl; Pentadecane, 7-methyl; Octane, 2,3,7-trimethyl; Dodecane, 3-methyl; Dodecane, 2,6,10-trimethyl; $1 \mathrm{H}$-Indene, octahydro-2,2,4,4,7,7-hexamethyl-, trans; Undecane, 5-cyclohexyl; H26:Undecane, 4,8-dimethyl; Decahydro-4,4,8,9,10pentamethylnaphthalene; Pentadecane, 2-methyl; Pentadecane, 2,6,10-trimethyl; Pentadecane, 8-hexyl; Hexadecane; 2,6,10,14-tetramethyl; Ethyl iso-allocholate
Kit following the standard protocol prescribed by the manufacturer.

\section{Genome sequencing and assembly}

The complete genome sequence of DX4 was sequenced using Illumina HiSeq2000 for the initial sequencing and assembly, followed by PacBio sequencing to fully close the genome sequence $[18,19]$. The Illumina platform generated 1,864,026 reads totaling 561,071,826 bp, and the data were assembled into 9 scaffolds by using SOAP denovo V2.3 [20]. The coverage of the paired-end reads was $86 \times$. For gap closure, sequencing was performed using a PacBio SMRT cell, which resulted in 198,008 reads with an average read length of $4973 \mathrm{bp}$ and a coverage of $153 \times$. The alignment of the PacBio reads were assembled with HGAP [21]. Gap closure was managed using the Gap Closer 1.12 and resulting in the final genome of one complete chromosome. This finished genome was deposited in IMG Database with the Project ID: Gp0156107. And this whole-genome project (BioProject ID: PRJNA339039) has also been registered and assembled sequence data submitted at NCBI GenBank under the accession no.CP017141. The Average Nucleotide Identity (ANI) analysis has been carried out by using a online tool [22].

\section{Genome annotation}

Glimmer 3.0 was used to predict open reading frames (ORFs) [23]. The rRNA and tRNA gene predictions and the ORFs annotation were conducted by using BLASTp against NCBI-NR database [24], the COG database [25] and the KEGG database [26]. Genes function annotations were assigned when blastp E-values were $\leq 0.001$ [27]. If there was no significant similarity to protein in other organisms, the gene production was described as hypothetical protein.

\section{Genome properties}

The genome statistics is shown in Table 3 . The genome of Pedobacter steynii DX4 is 6,581,659 base pairs in size, and has a GC content of $41.31 \%$. Out of the total 5464 genes, 23 genes are pseudogenes and 63 are tRNAs, 13 are rRNA genes, 3 are ncRNA genes, 5362 are coding sequences CDSs. Of the total CDSs, 307 are functioning unknown (5.7\%), 414 are general function prediction only $(7.7 \%)$ and the remaining had a defined function. The COGdistribution of genes is shown in Table 4. The genome map (Fig. 5) was visualized by CG view server. The ANI analysis showed Pedobacter steynii DX4 had 83.33\% nucleotide identity with Pedobacter steynii DSM 19110. Comparative analysis between Pedobacter strains isolated from polar region was also performed. The P. steynii DX4 presented $79.03 \%$ nucleotide identity with $P$. cryoconitis PAMC 27485 (isolated from Antarctica), 78.42\% with $P$. antarcticus $4 B Y$ and $76.39 \%$ with $P$. arcticus A12, revealing the great genetic distance between these strains. 


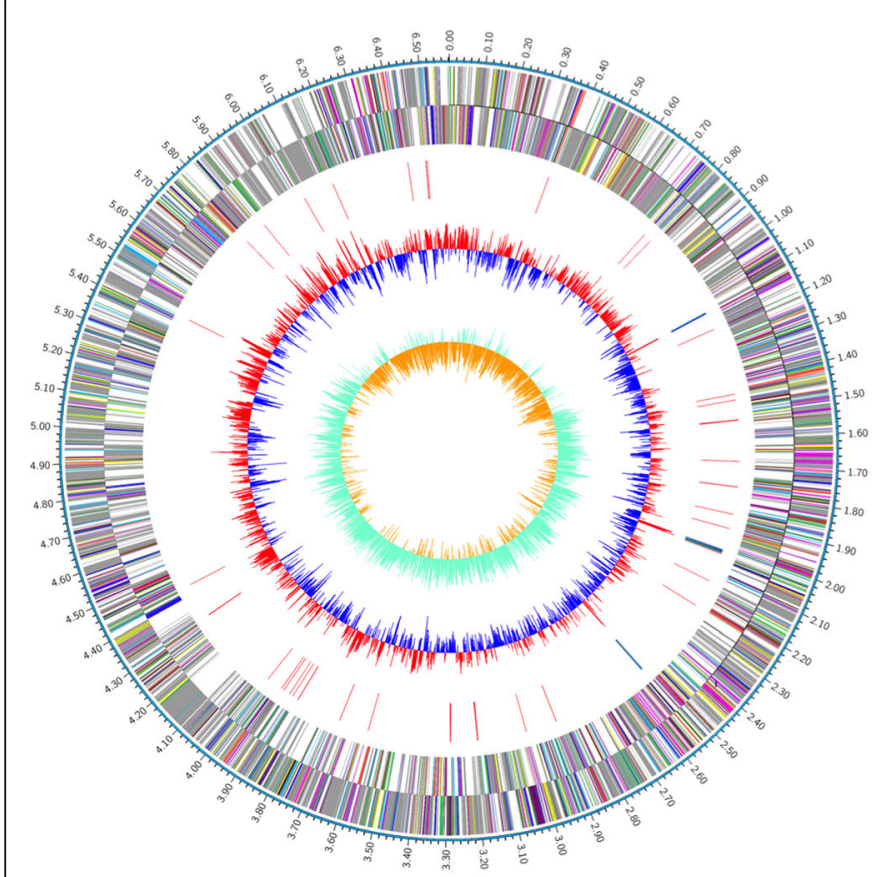

$\square$ B: Chromatin structure and dynamics
$\square$ C: Energy production and conversion
$\square$ D: Cell division and chromosome partitioning
$\square$ E: Amino acid transport and metabolism
$\square$ F: Nucleotide transport and metabolism
$\square$ G: Carbohydrate transport and metabolism
H: Coenzyme metabolism
$\square_{\text {I: Lipid metabolism }}$
J: Translation, ribosomal structure and biogenesis
K: Transcription
$\square$ L: DNA replication, recombination, and repair
M: Cell envelope biogenesis, outer membrane
N: Cell motility and secretion
$\square$ O: Posttranslational modification, protein turnover chaperones
P: Inorganic ion transport and metabolism
Q: Secondary metabolites biosynthesis, transport and catabolism
$\square$ R: General function prediction only
$\square$ S: Function unknown
$\square$ T: Signal transduction mechanisms
$\square$ U: Intracellular trafficking, secretion, and vesicular transport
V: Defense mechanisms
$\square$ No assigned COG

Fig. 4 Rooted phylogenetic tree of the $16 \mathrm{~S}$ rRNA sequences of Pedobacter steynii strain DX4 and relative species. The $16 \mathrm{~S}$ rRNA sequences of Pedobacter species were aligned, and the phylogenetic tree was constructed by using Neighbor-joining method based on the maximum composite likehood substitution model

\section{Insights from the genome sequence}

Genome annotation predicted many traits support the adaptability of DX4 to cold and crude oil-contaminated environment. The Five cold shock proteins were predicted (NCBI Protein database: WP_069377418.1,

Table 2 Project information of the whole genome sequence of P. steynii DX4

\begin{tabular}{|c|c|c|}
\hline MIGS ID & Property & Term \\
\hline MIGS-31 & Finishing quality & Finished \\
\hline MIGS-28 & Libraries used & $\begin{array}{l}\text { Paired-end (average } 500 \text { bp) } \\
\text { PacBio (2075 and } 2775 \text { kbp) }\end{array}$ \\
\hline MIGS-29 & Sequencing platforms & Illumina Hiseq 2000 and PacBio \\
\hline MIGS-31.2 & Fold coverage & $\begin{array}{l}\text { Illumina paired-end:86x } \\
\text { PacBio: } 153 x\end{array}$ \\
\hline MIGS-30 & Assemblers & $\begin{array}{l}\text { SOAPdenovo 2.3, } \\
\text { GapCloser v1.12 } \\
\text { HGAP }\end{array}$ \\
\hline \multirow[t]{6}{*}{ MIGS-32 } & Gene calling method & Glimmer3.02 \\
\hline & Locus Tag & BFS30 \\
\hline & GenBank ID & СР017141 \\
\hline & GenBank Date of Release & September 9, 2016 \\
\hline & GOLD ID & Gp0156107 \\
\hline & BIOPROJECT & PRJNA339039 \\
\hline \multirow[t]{2}{*}{ MIGS-13 } & Source Material Identifier & DX4 \\
\hline & Project relevance & Biodegrading \\
\hline
\end{tabular}

WP_062548063.1, WP_048905418.1, WP_008241764.1 and AOM75720.1). These proteins are supposed to play important roles in low temperature conditions [28]. The related strians isolated from antarctic regions, Pedobacter antarcticus 4BY and Pedobacter cryoconitis PAMC 27485, respectively encoded four cold shock proteins. Based on the COG analysis, 261

Table 3 Genome statistics

\begin{tabular}{lll}
\hline Attribute & Value & \% of Total \\
\hline Genome size (bp) & $6,581,659$ & 100 \\
DNA coding (bp) & $6,033,402$ & 91.67 \\
DNA G + C (bp) & $2,718,883$ & 41.31 \\
DNA scaffolds & 1 & \\
Total genes & 5464 & 100 \\
Protein coding genes & 5362 & 98.13 \\
RNA genes & 79 & 1.44 \\
Pseudo genes & 23 & 0.42 \\
Genes in internal clusters & NA & \\
Genes with function prediction & 414 & 7.58 \\
Genes assigned to COGs & 3720 & 68.01 \\
Genes with Pfam domains & 4264 & 78.04 \\
Genes with signal peptides & 804 & 14.71 \\
Genes with transmembrane helices & 178 & 3.26 \\
CRISPR repeats & 1 & \\
\hline
\end{tabular}


Table 4 Number of genes of Pedobacter steynii DX4 with the general COG functional categories

\begin{tabular}{|c|c|c|c|}
\hline Code & Value & $\%$ of total ${ }^{a}$ & Description \\
\hline J & 155 & 2.9 & Translation, ribosomal structure and biogenesis \\
\hline A & 0 & 0 & RNA processing and modification \\
\hline K & 417 & 7.8 & Transcription \\
\hline L & 146 & 2.7 & Replication, recombination and repair \\
\hline B & 1 & 0 & Chromatin structure and dynamics \\
\hline D & 20 & 0.4 & Cell cycle control, Cell division, chromosome partitioning \\
\hline V & 94 & 1.8 & Defense mechanisms \\
\hline $\mathrm{T}$ & 261 & 4.9 & Signal transduction mechanisms \\
\hline M & 306 & 5.7 & Cell wall/membrane biogenesis \\
\hline N & 17 & 0.3 & Cell motility \\
\hline U & 29 & 0.5 & Intracellular trafficking and secretion \\
\hline $\mathrm{O}$ & 158 & 2.9 & Posttranslational modification, protein turnover, chaperones \\
\hline C & 150 & 2.8 & Energy production and conversion \\
\hline G & 255 & 4.8 & Carbohydrate transport and metabolism \\
\hline E & 257 & 4.8 & Amino acid transport and metabolism \\
\hline $\mathrm{F}$ & 74 & 1.4 & Nucleotide transport and metabolism \\
\hline $\mathrm{H}$ & 125 & 2.3 & Coenzyme transport and metabolism \\
\hline । & 154 & 2.9 & Lipid transport and metabolism \\
\hline P & 290 & 5.4 & Inorganic ion transport and metabolism \\
\hline Q & 90 & 1.7 & Secondary metabolites biosynthesis, transport and catabolism \\
\hline $\mathrm{R}$ & 414 & 7.7 & General function prediction only \\
\hline S & 307 & 5.7 & Function unknown \\
\hline- & 1642 & 30.6 & Not in COGs \\
\hline
\end{tabular}

${ }^{\mathrm{a}}$ The total is based on the total number of protein coding genes in the genome

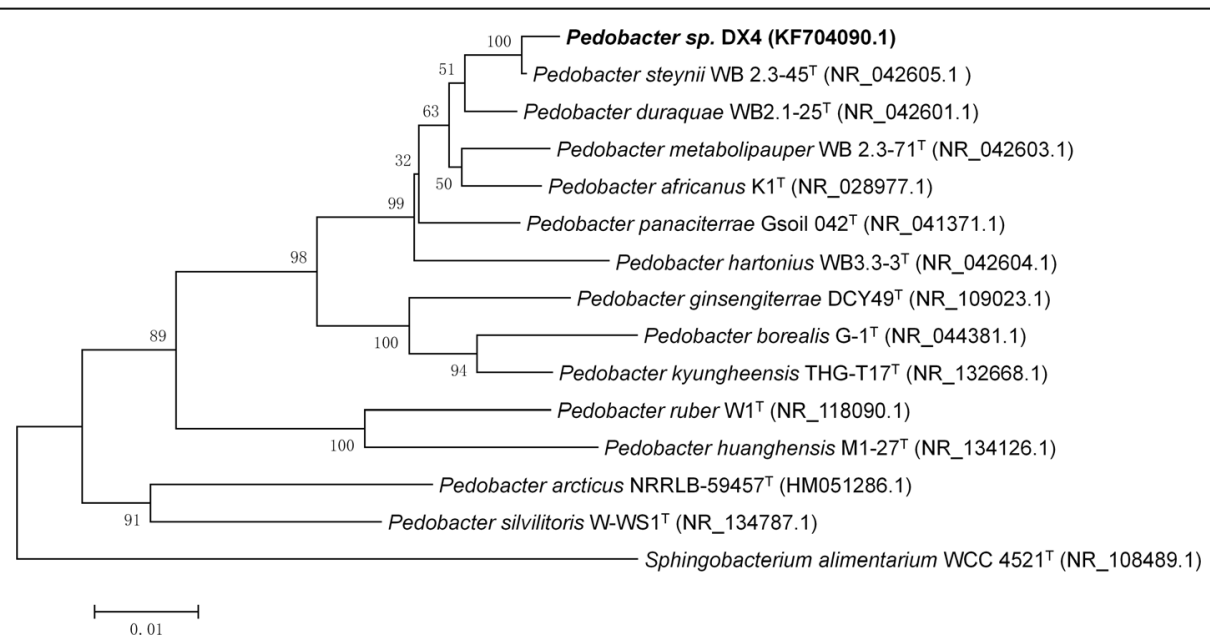

Fig. 5 The genome map of Pedobacter steynii strain DX4.Circle 1: Base pair numbers; Circle 2 and Circle 3:Forward and reverse coding domain sequences, the color coding of the CDS represent different Clusters of Orthologous Groups categories; Circle 4: rRNA and tRNA; Circle 5: \% GC plot; Circle 6:GC skew $[(G C) /(G+C)]$ 
genes in total were assigned to the signal transduction category. Among them, 22 genes were predicted to encode the response regulators and 6 were found to encode chemotaxis protein CheY [29]. These genes could play regulatory role in environment sensing and cell motility towards the crude oil.

As for aerobic alkane degradation, alkB gene has been considered as a functional biomarker for alkane-degrading bacterial populations in environmental [30-32]. But in $P$. steynii DX4 genome, no alkB homolog coding genes were found. A gene coding for haloalkane dehalogenase (WP_069382597.1, EC 3.8.1.5) was annotated. Haloalkane dehalogenase (HLD) has considerable environmental significance because it converts haloalkanes to corresponding alcohol and hydrogen halide (KEGG database: RN: R02337,) [33, 34]. In addition to that, three luciferase proteins were identified (WP_069377707.1, WP_069380456.1 and WP_069377640.1). Research showed that the bacteria luciferase can utilize reduced FMN in the oxidation of alkanes with the emission of blue-green light $[35,36]$. Figure 6 shows the genes coding for HLD and luciferase protein and adjacent genes upstream and downstream, which may be relevant genes participating in the metabolism of crude oil. In addition, the presence of 19 alcohol dehydrogenase and 23 aldehyde dehydrogenase necessary for alkane degradation as well as 11 fatty acid transport and metabolism genes suggest a complete alkane degradation pathway [37, 38].

The antibiotics and secondary metabolite analysis was done using the anti-SMASH platform [39]. In total, 12 secondary metabolite clusters were identified and 11 of them were related to antibiotics. A resorcinol metabolite cluster was identified and this cluster may play important role in the degradation of resorcinol and other aromatic compounds [40]. Interestingly, the 12 secondary metabolite clusters had no similarity with the known clusters, suggesting that the P. steynii strain DX4 may possess novel secondary metabolic pathways.

\section{Conclusions}

Pedobacter steynii DX4 was isolated from a cold environment and could utilize crude oil as sole carbon source. The genome of DX4 reported here provides the genetic basis of its crude oil biodegrading mechanism. Genes involved in cold shock, energy conversion and response regulators for cell motility point to the unique abilities of DX4 in oil degradation and cold environment adaptation. Genomic research on DX4 would also provide a blueprint for the application of bioremediation and recovery in cold oil-polluted environments.

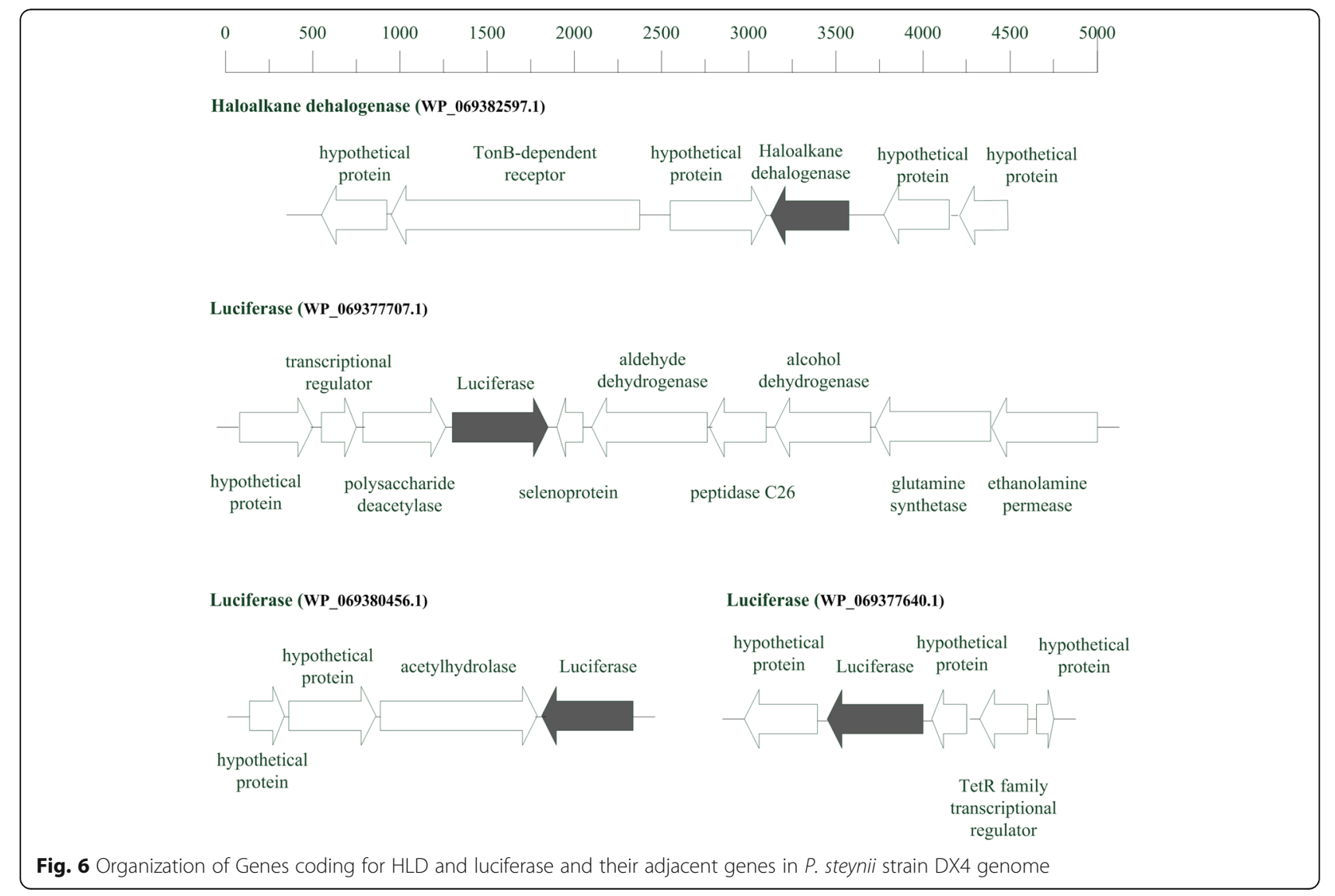




\section{Abbreviation}

ANI: Average nucleotide identity; HLD: Haloalkane dehalogenase

\section{Funding}

This study is supported by grants from the International Scientific and Technological Cooperation Projects of the Ministry of Science and Technology (2014DFA30330), the National Science Foundation of China (41271265).

\section{Authors' contributions}

SJC and GSZ initiated the study. GSZ, TC and GXL designed the research and project outline. SJC, GSZ and XMC drafted the manuscript. HZL and YLW isolated the strain. SJC and XMC assembled and annotated the genome. All authors read and approved the final manuscript.

\section{Competing interests}

The authors declare that they have no competing interests.

\section{Author details}

'University of Chinese Academy of Sciences, No.19A Yuquan Road, Beijing 100049, China. ${ }^{2}$ State Key Laboratory of Cryospheric Sciences, Northwest Institute of Eco-Environment and Resources, Chinese Academy of Sciences, Lanzhou 730000, China. ${ }^{3}$ Key Laboratory of Extreme Environmental Microbial Resources and Engineering, Gansu Province 730000, China. ${ }^{4}$ Key Laboratory of Desert and Desertification, Northwest Institute of Eco-Environment and Resources, Chinese Academy of Sciences, Lanzhou 730000, China. ${ }^{5}$ College of Bioscience and Bioengineering, Jiangxi Agricultural University, Nanchang, Jiangxi 330045, China.

\section{Received: 19 October 2016 Accepted: 29 June 2017}

Published online: 27 July 2017

\section{References}

1. Evans FF, Rosado AS, Sebastian GV, Casella R, Machado PL, Holmstrom C, et al. Impact of oil contamination and biostimulation on the diversity of indigenous bacterial communities in soil microcosms. FEMS Microbiol Ecol. 2004:49:295-305

2. Van Hamme JD, Singh A, Ward OP. Recent advances in petroleum microbiology. Microbiol Mol Biol Rev. 2003;67:503-49.

3. Walker J, Austin H, Colwell R. Utilization of mixed hydrocarbon substrate by petroleum-degrading microorganisms. J Gen Appl Microbiol. 1975;21:27-39.

4. Brown LR. Microbial enhanced oil recovery (MEOR). Curr Opin Microbiol. 2010;13:316-20.

5. Kimes NE, Callaghan AV, Suflita JM, Morris PJ. Microbial transformation of the Deepwater horizon oil spill-past, present, and future perspectives. Front Microbiol. 2014:5:603.

6. Megharaj M, Ramakrishnan B, Venkateswarlu K, Sethunathan N, Naidu R. Bioremediation approaches for organic pollutants: a critical perspective. Environ Int. 2011;37:1362-75.

7. Fernandez-Luqueno F, Valenzuela-Encinas C, Marsch R, Martinez-Suarez C, Vazquez-Nunez E, Dendooven L. Microbial communities to mitigate contamination of PAHs in soil-possibilities and challenges: a review. Environ Sci Pollut Res Int. 2011:18:12-30.

8. Das N, Chandran P. Microbial degradation of petroleum hydrocarbon contaminants: an overview. Biotechnol Res Int. 2011:2011:941810.

9. Yang Y, Wang J, Liao J, Xie S, Huang Y. Abundance and diversity of soil petroleum hydrocarbon-degrading microbial communities in oil exploring areas. Appl Microbiol Biotechnol. 2015;99:1935-46.

10. Vázquez S, Nogales B, Ruberto L, Mestre C, Christie-Oleza J, Ferrero M, et al. Characterization of bacterial consortia from diesel-contaminated Antarctic soils: towards the design of tailored formulas for bioaugmentation. Int Biodeterior Biodegr. 2013;77:22-30.

11. Sun W, Dong Y, Gao P, Fu M, Ta K, Li J. Microbial communities inhabiting oil-contaminated soils from two major oilfields in northern China: implications for active petroleum-degrading capacity. J Microbiol. 2015:53:371-8.

12. Margesin R. Pedobacter cryoconitis sp. nov., a facultative psychrophile from alpine glacier cryoconite. Int J Syst Evol Microbiol. 2003:53:1291-6.

13. Wang B, Lai Q, Cui Z, Tan T, Shao Z. A pyrene-degrading consortium from deep-sea sediment of the West Pacific and its key member Cycloclasticus sp. P1. Appl Environ Microbiol. 2008;10:1948-63.
14. Wang W, Wang L, Shao Z. Diversity and abundance of oil-degrading bacteria and alkane hydroxylase (alkB) genes in the subtropical seawater of Xiamen Island. Adv Microb Ecol. 2010;60:429-39.

15. Whyte LG, Bourbonniére L, Greer CW. Biodegradation of petroleum hydrocarbons by psychrotrophic pseudomonas strains possessing both alkane (alk) and naphthalene (nah) catabolic pathways. Appl Environ Microbiol. 1997;63:3719-23.

16. Seemüller E, Schneider B, Mäurer R, Ahrens U, Daire X, Kison H, et al. Phylogenetic classification of phytopathogenic mollicutes by sequence analysis of 165 ribosomal DNA. Int J Syst Bacteriol. 1994;44:440-6.

17. Saitou N, Nei M. The neighbor-joining method: a new method for reconstructing phylogenetic trees. Mol Biol Evol. 1987;4:406-25.

18. Bosma EF, Koehorst JJ, van Hijum SA, Renckens B, Vriesendorp B, van de Weijer $\mathrm{AH}$, et al. Complete genome sequence of thermophilic Bacillus Smithii type strain DSM 4216(T). Stand Genomic Sci. 2016;11:52.

19. Quail MA. Smith M, Coupland P, Otto TD, Harris SR, TR Connor, et al. a tale of three next generation sequencing platforms: comparison of ion torrent, Pacific biosciences and Illumina MiSeq sequencers. BMC Genomics. 2012;13:1-13.

20. Luo R, Liu B, Xie Y, Li Z, Huang W, Yuan J, et al. SOAPdenovo2: an empirically improved memory-efficient short-read de novo assembler. Gigascience. 2012;1:1-6.

21. Chin CS, Alexander DH, Marks P, Klammer AA, Drake J, Heiner C, et al. Nonhybrid, finished microbial genome assemblies from long-read SMRT sequencing data. Nat Meth. 2013;10:563-9.

22. Operon Prediction Tool. http://enve-omics.gatech.edu/. Accessed 15 Jan 2017.

23. Delcher AL, Bratke KA, Powers EC, Salzberg SL. Identifying bacterial genes and endosymbiont DNA with glimmer. Bioinformatics. 2007;23:673-9.

24. The Nucleotide database. https://www.ncbi.n/m.nih.gov/nucleotide/. Accessed 12 July 2017.

25. The Clusters of Orthologous Groups database. https://www.ncbi.nlm.nih gov/COG/. Accessed 12 July 2017.

26. Kyoto Encyclopedia of Genes and Genomes Database. http://www.kegg.jp/. Accessed 12 July 2017

27. Kelley LA, Sternberg MJ. Protein structure prediction on the web: a case study using the Phyre server. Nat Protoc. 2009;4:363-71.

28. Chattopadhyay MK. Mechanism of bacterial adaptation to low temperature. J Biosci. 2006;31:157-65.

29. Bourret RB, Hess JF, Simon MI. Conserved aspartate residues and phosphorylation in signal transduction by the chemotaxis protein CheY. Proc Natl Acad Sci U S A. 1990:87:41-5.

30. Emanuele K, Sebben BG, Helena PV. New alk genes detected in Antarctic marine sediments. Appl Environ Microbiol. 2009;11:669-73.

31. Wallisch S, Gril T, Dong X, Welzl G, Bruns C, Heath E, et al. Effects of different compost amendments on the abundance and composition of alkB harboring bacterial communities in a soil under industrial use contaminated with hydrocarbons. Front Microbiol. 2014:5:96

32. Wang W, Wang L, Shao Z. Diversity and abundance of oil-degrading bacteria and alkane hydroxylase (alkB) genes in the subtropical seawater of Xiamen Island. Microb Ecol. 2010;60:429-39.

33. Verschueren KH, Seljée F, Rozeboom HJ, Kalk KH, Dijkstra BW. Crystallographic analysis of the catalytic mechanism of haloalkane dehalogenase. Nature. 1993;363:693-8.

34. Janssen DB. Evolving haloalkane dehalogenases. Curr Opin Chem Biol. 2004;8:150-9.

35. Ellis HR. The FMN-dependent two-component monooxygenase systems. Arch Biochem Biophys. 2010;497:1-12.

36. Li L, Liu X, Yang W, Xu F, Wang W, Feng L, et al. Crystal structure of longchain alkane monooxygenase ( $\mathrm{Lad} A$ ) in complex with coenzyme FMN: unveiling the long-chain alkane hydroxylase. J Mol Biol. 2008;376:453-65.

37. Bowman JS, Deming JW. Alkane hydroxylase genes in psychrophile genomes and the potential for cold active catalysis. BMC Genomics. 2014;15:1120.

38. Nie $Y$, Tang YQ, Li Y, Chi CQ, Cai M, Wu XL, et al. Nce of Polymorphum gilvum SL003B-26A1T reveals its genetic basis for crude oil degradation and adaptation to the saline soil. PLOS One. 2012:7:e31261.

39. Helfrich EJ, Reiter S, Piel J. Recent advances in genome-based polyketide discovery. Curr Opin Biotechnol. 2014;29C:107-15.

40. Kumari B, Singh SN, Singh DP. Characterization of two biosurfactant producing strains in crude oil degradation. Process Biochem. 2012:47:2463-71.

41. Woese CR, Kandler O, Wheelis ML. Towards a natural system of organisms: proposal for the domains Archaea, bacteria, and Eucarya. Proc Natl Acad Sci U S A. 1990:87:4576-9. 
42. Euzeby J. List of new names and new combinations previously effectively, but not validly, published-Validation List no. 118. Int J Syst Evol Microbiol. 2007;57:2449-50.

43. Krieg NR, Ludwig W, Euzéby J, Whitman WB. Phylum XIV. Bacteroidetes phyl. Nov: Springer; 2010. p. 25-New York, 469.

44. Kämpfer $\mathrm{P}$, Lodders N, Martin K, Avendaño-Herrera R. Flavobacterium Chilense sp. nov. and Flavobacterium araucananum sp. nov., isolated from farmed salmonid fish. Int J Syst Evol Microbiol. 2012;62:1402-8.

45. Bell TH, Yergeau E, Martineau C, Juck D, Whyte LG, Greer CW. Identification of nitrogen-incorporating bacteria in petroleum-contaminated arctic soils by using [15N]DNA-based stable isotope probing and pyrosequencing. Appl Environ Microbiol. 2011;77:4163-71.

46. Kämpfer P. Sphingobacteriia class. nov. Hoboken: Wiley; 2015.

47. Steyn PL, Segers P, Vancanneyt M, Sandra P, Kersters K, Joubert JJ. Classification of heparinolytic bacteria into a new genus, Pedobacter, comprising four species: Pedobacter heparinus comb. nov., Pedobacter piscium comb. nov., Pedobacter africanus sp. nov. and Pedobacter saltans sp. nov. proposal of the family Sphingobact. Int J Syst Bacteriol. 1998;48(Pt 1):165-77.

48. Validation EJ, No L. 143. List of new names and new combinations previously effectively, but not validly, published. Int J Syst Evol Microbiol. 2012:62:1-4.

49. Muurholm S, Cousin S, Päuker O, Brambilla E, Stackebrandt E. Pedobacter duraquae sp. nov., Pedobacter westerhofensis sp. nov., Pedobacter metabolipauper sp. nov., Pedobacter hartonius sp. nov. and Pedobacter steynii sp. nov., isolated from a hard-water rivulet. Int I Syst Evol Microbiol. 2007:57:2221-7.

50. Margesin R, Spröer C, Schumann P, Schinner F. Pedobacter cryoconitis sp nov., a facultative psychrophile from alpine glacier cryoconite. Int I Syst Evol Microbiol. 2003;53:1291-6.

51. Shivaji S, Chaturved P, Reddy GS, Suresh K. Pedobacter himalayensis sp. nov. from the Hamta glacier located in the Himalayan mountain ranges of India. Int J Syst Evol Microbiol. 2005;55:1083-8.

\section{Submit your next manuscript to BioMed Central and we will help you at every step:}

- We accept pre-submission inquiries

- Our selector tool helps you to find the most relevant journal

- We provide round the clock customer support

- Convenient online submission

- Thorough peer review

- Inclusion in PubMed and all major indexing services

- Maximum visibility for your research

Submit your manuscript at www.biomedcentral.com/submit 